\title{
Influences and Outcomes: A Systematised Review of Reflective Teaching Strategies in Student Healthcare Placements
}

\author{
Michael Dunne \\ University of Sydney, Australia; \\ Westmead Hospital, New South Wales, Australia \\ and \\ Health Education and Training Institute (HETI), Australia \\ Gillian Nisbet \\ University of Sydney, Australia \\ Merrolee Penman \\ University of Sydney, Australia \\ Lindy McAllister \\ University of Sydney, Australia
}

\begin{abstract}
The development of reflection in tertiary students benefits from facilitation. Educators commonly facilitate the development of affective, cognitive, and meta-cognitive skills associated with reflection. Reflective teaching strategies, that is, guiding comments or questions used within an activity to stimulate cognitive processes, are strategies used by educators to facilitate reflection. This systematised review focuses on the approaches used to measure influences and outcomes of the teaching of reflection in order to enhance educators' understanding of recent evidence for use in the placement setting. The review explores what outcome measures are used in current research, and how the evidence incorporates contextual factors such as time, safety, mentorship, supervision, and emotional and intellectual support to develop reflection in students. Systematised searching of CINAHL ${ }^{\circledR}$, ProQuest, ERIC, OvidSP, Scopus ${ }^{\circledR}$, and Web of Science ${ }^{\mathrm{TM}}$ databases for the period 2005 to 2015 identified 26 studies, from a pool of 6968 that met the inclusion criteria. Results indicate that a range of reflective teaching strategies are being used by allied and oral health, nursing, and the medical professions that assist movement towards critical reflection. No direct connection between this movement and the presence of contextual factors was established. Review outcomes are limited by the variable quality of the included studies and the lack of high quality tools for measurement of teaching effect on the development of reflection. We recommend that future studies into the use of reflective teaching strategies continue to incorporate contextual factors in combination with valid and reliable measurement practices in the workplace.
\end{abstract}

Keywords: outcome assessment (health care); reflection; students; workplace 
${ }^{*}$ Corresponding Author: Michael Dunne, Work Integrated Learning, Faculty of Health Sciences,

University of Sydney, New South Wales, Australia...

Email: michaeldunne.speech@gmail.com

Journal URL: http://e-learning.coventry.ac.uk/ojs/index.php/pblh

Dunne, M., Nisbet, G., Penman, M., and McAllister, L. (2016) 'Influences and Outcomes: A Systematised Review of Reflective Teaching Strategies in Student Healthcare Placements'. International Journal of Practice-based Learning in Health and Social Care, 4 (1), 55-77 doi: 10.18552/ijpblhsc.v4i1.342

(C) 2016 Michael Dunne, Gillian Nisbet, Merrolee Penman, and Lindy McAllister. This Open Access article is distributed under the terms of the Creative Commons Attribution Non-Commercial License 4.0 International License (http://creativecommons.org/licenses/by-nc/4.0/), which permits unrestricted noncommercial use, distribution, and reproduction in any medium, provided the original work is properly cited. 


\section{Introduction}

The development of reflection is not innate (Driessen et al. 2008); it requires facilitation (Ip et al. 2012, Plack, Dunfee, and Rindflesch 2008). Reflection provides tertiary healthcare students with a generic means of furthering skill and knowledge development within a lifelong learning context (Donovan 2007, Mamede and Schmidt 2004, Paget 2001, Roche and Coote 2008, Stark et al. 2006). The placement environment is a complex learning context for students in allied health (for example speech pathology, physiotherapy, radiation therapy), medicine, and nursing that predominantly occurs in workplace settings such as healthcare centres, private practice, hospitals, non-government organisations, and university clinics. Placements enable students to connect theory to practice, as well as take advantage of practice-based learning supports within their chosen profession, for example supervision and mentoring. The use of reflection within this practice-based learning context is a common education practice facilitated by clinical educators. The development and practice of reflection leads to increased self-efficacy in performance within nursing and allied health (Kuiper, Murdock, and Grant 2010, Levine, Kern, and Wright 2008), and increased diagnostic accuracy in medicine (Mamede et al. 2010). Reflection in turn is theorised to assist students to integrate theory and knowledge with their understandings gained from experience (Boud, Keogh, and Walker 1985, Schön 1987).

The increasing number of theoretical papers and experimental investigations of reflection in health education literature is illustrated by the numerous definitions of reflection and interpretations of these definitions (Aronson et al. 2011, Mann, Gordon, and MacLeod 2009, White Fook, and Gardner 2006) that have commonly been based on popular seminal works of Boud, Keogh, and Walker (1985) and Schön (1987). For the purpose of this review, reflection within the context of healthcare practice-based education is defined as "a generic term for those intellectual and affective activities in which individuals engage to explore their experiences in order to [gain] a new understanding and appreciation" (Boud, Keogh, and Walker 1985: 19). The definition of reflection can be further refined according to timing of the reflective action in relation to the event that is being reflected upon and by depth of reflection by the learner. The timing of implementing reflection and its effect on depth has been explored by Teekman (2000) and the seminal authors Schön (1987) and Boud, Keogh, and Walker (1985). These authors explored the effect of pre-emptive or 'for action' reflection (Teekman 2000); during or 'in action' reflection (Schön 1987); and post or 'on action' reflection (Boud, Keogh, and Walker 1985). The 'timing' variable in reflection plays an important role in the reflectee's motivation to engage in the process and the role that doubt, uncertainty, and/or the presence of conflict can have during professional practice. The focus of recent investigations is predominantly 'on-action' (Aronson et al. 2012, Findlay, Dempsey, and Warren-Forward 2011). This focus as discussed in Mann, Gordon, and MacLeod (2009) is likely secondary to the methodological challenges present in measuring reflection 'for action' and 'in action'. The proficiency with which students use reflective thinking processes in the clinical setting at any time point follows a continuum of reflective depth, from the non-reflective describer to the critical reflector. "Critical reflection is the process by which adults identify the assumptions governing their actions, locate the historical and cultural origins of the assumptions, question the meaning of the assumption, and develop alternative ways of acting" (Stein 2000: 1).

Descriptors used in the literature to gauge progress along this continuum of depth of reflection vary. Boud, Keogh, and Walker (1985) and Mezirow (1990) describe their understanding of the process of reflection using six and three elements respectively (Figure 1). The affective, cognitive, and meta-cognitive elements described by Boud, Keogh, and Walker (1985) and contained within Mezirow's reflective concept do not follow a linear hierarchy, rather, as more of each element becomes present in the reflectee's understanding, the more critical reflection is thought to be. A third seminal author (Schön 1987) emphasises the cyclical nature of reflection. The artistry in framing, hypothesis testing, and re-framing an incident (Schön 1987) provides the reflectee with ongoing opportunities for changes to affective, cognitive, and meta-cognitive processes that lead to critical understandings, or to continue after an extract. 
Figure 1. Reflective continuum

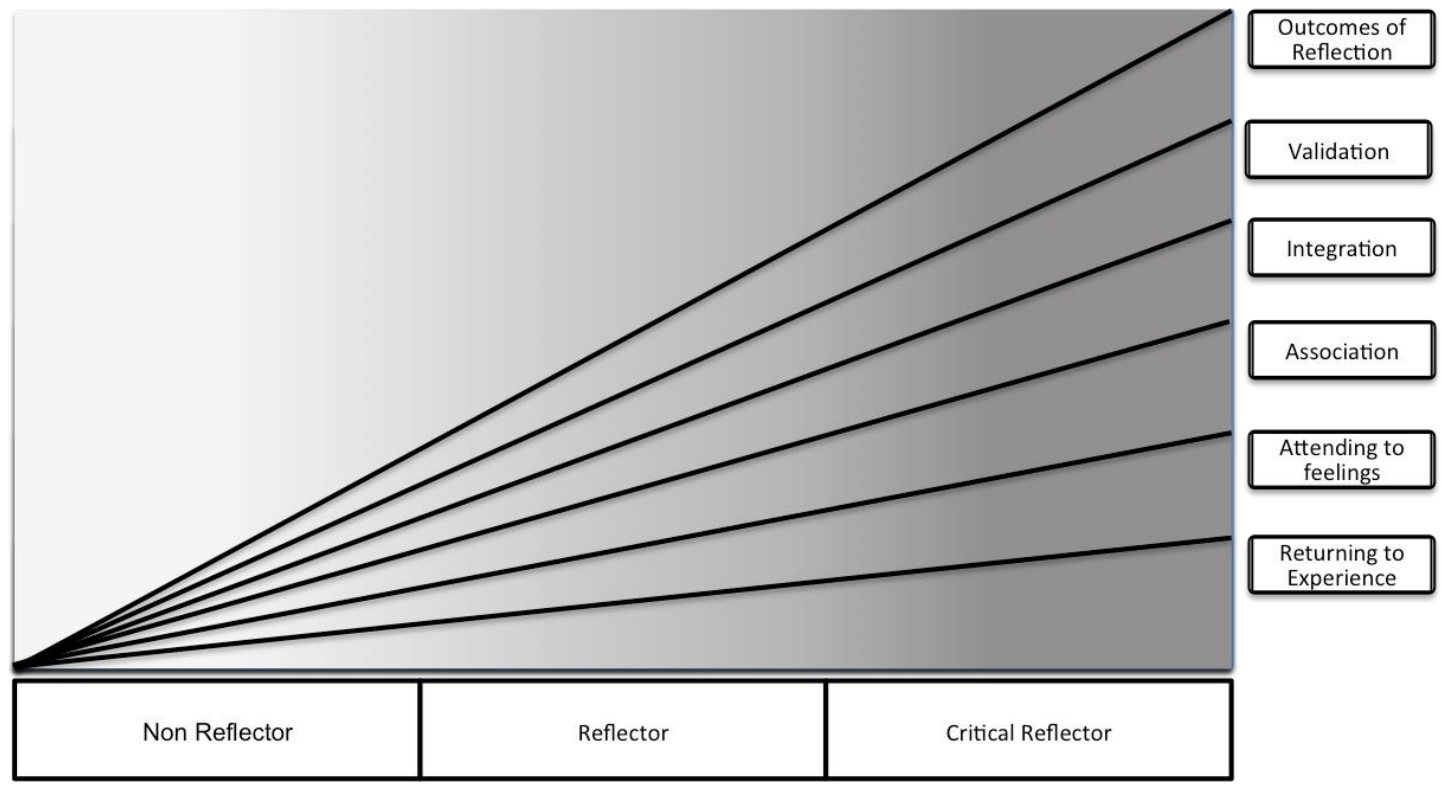

Reflective elements based on Mezirow (1990) and Boud, Keogh, and Walker (1985) shown in relation to each other. The grey scale gradient in the background represents reflective depth, or quality in the presence of each element.

Studies have used both reflective frameworks and reflection activities to assist student reflection whilst they are on clinical placement. In turn, educators use this combination of reflection frameworks and reflection activities to assist students in their journey towards critical reflection. Reflective frameworks, when used by educators in a placement context, are defined as a set of guiding comments, questions, or statements that stimulate an individual to explicitly or implicitly build thinking strategies associated with an incident in a cyclical manner - see, for example, Plack, Dunfee, and Rindflesch (2008). These guiding frameworks are often reported in combination with a variety of reflective activities that enable students to communicate reflective outcomes including blogs (Wright and Lundy 2012), journaling (Dye et al. 2011), seminars (Beylefeld, Nena, and Prinsloo 2005), individual and small group discourse (Peterkin et al. 2012, Toy et al. 2009), electronic programs (Thomas and Goldberg 2007), storyboards (Lillyman, Gutteridge, and Berridge 2011), portfolios (Gordon 2003), and written narratives (Kleinheksel 2014, Lasater and Nielsen 2009). In this review, the combination of reflective frameworks and reflective activities are referred to as reflective teaching strategies. Whilst these are two separate facets, the combination provides a manner that enables students to communicate reflective outcomes that may be measured.

Over the past 10 years, studies utilising a reflective teaching strategy can be seen to use two broad teaching approaches that aim to progress students along the depth continuum from surface descriptions to critical perspectives. A 'Process' approach (Hill, Davidson, and Theodoros 2012, Ip et al. 2012, Plack, Dunfee, and Rindflesch 2008) follows a gradual course that is used repetitively over time to increase depth of reflection in a developmental manner. Conversely, a 'Vertical' approach (Chretien, Goldman, and Faselis 2008, Stark et al. 2006) is designed to transition the learner (or reflectee) from surface to deep, or critical, reflection within the one occasion. This approach is often more detailed and resource intensive than a Process approach (Mann, Gordon, and MacLeod 2009). It has yet to be determined if a particular teaching approach is best suited to improving the reflective proficiency of students.

Educators can use a reflective continuum to gauge students' reflection. This continuum, in turn, can support educators' decisions surrounding the need to provide student support. Ideally, educators use measurement or analysis to accurately identify where on the reflective continuum 
a student sits in order to support their judicious use of teaching strategies. The majority of research to date has used qualitative content analysis of students' reflective journals as a measurement strategy. Although valuable, this is a resource intensive approach that is challenging to implement in the workplace due to the time and expertise required.

Translation of insights gained from research exploring the use of reflection by educators into actual workplaces is vital. Mann, Gordon, and MacLeod (2009) identified that the most influential elements in "enabling the development of reflection" (Mann, Gordon, and MacLeod 2009: 608) are emotional and intellectual support, mentoring, time, safety in the expression of opinions, and supervision practices that accommodate individual learner styles. Given this positive influence, it presents educators and researchers alike with evidence for the inclusion of these contextual factors into reflective teaching strategies in order to achieve optimal outcomes.

Implementation of a growing quantity of evidence is an ongoing challenge faced by educators. The range and diversity of reflective teaching strategies are matched with an assortment of definitions, and resource intensive measurement methods used for the interpretation of reflection across an array of modalities. Owing to this complexity of intertwined concepts and practices, educators face a difficult task in judiciously using the evidence to implement an approach that supports the development of reflection in students.

This review focuses on the approaches used to measure influences and outcomes of the teaching of reflection in students whilst they are on clinical placement. It will explore what evidence there is to support the use of reflective teaching strategies in professional healthcare clinical education; what, if any measures have been used in current research; and how current research is integrating the use of contextual factors to support student reflection.

\section{Method}

A systematised search (Grant and Booth 2009) was undertaken of the CINAHL®, ProQuest, ERIC, OvidSP, Scopus®, and Web of Science ${ }^{\text {TM }}$ databases for the period 2005 to 2015 . This timeframe was decided upon as the last major review of this topic (Mann, Gordon, and MacLeod 2009) encompassed papers up to 2005. Search terms gathered from keywords used in seminal and frequently cited papers on this subject were utilised in order to cover the wide variety of terms used to describe reflection and its associated outcomes (Table 1 ).

Table 1. Search terms

\begin{tabular}{|c|c|c|}
\hline Population & Intervention & Outcomes \\
\hline $\begin{array}{l}\text { "Allied Health Student*", } \\
\text { "Health Science* Student*", } \\
\text { "Nursing Student*", } \\
\text { "Medical Student*","Health } \\
\text { Occupation Student"" }\end{array}$ & $\begin{array}{l}\text { "Reflective Journal*", "Reflective } \\
\text { Portfolio", "Reflective Narrative*", } \\
\text { "Reflective Activit*", "Critical } \\
\text { incident technique", "Critical } \\
\text { conversation*", "Critical } \\
\text { conversation*", "Reflective } \\
\text { cognitive process"", "Reflective } \\
\text { framework", "Reflective model", } \\
\text { "Reflective tool", "Reflect* } \\
\text { program", "Reflecti* technique", } \\
\text { "Reflect* strateg*", "Reflective } \\
\text { learning framework" }\end{array}$ & $\begin{array}{l}\text { Reflection, "Critical } \\
\text { thinking", "Critical Reflect*", } \\
\text { "Reflect* practice", } \\
\text { "transformational thinking", } \\
\text { "Critical awareness", } \\
\text { "Critical consciousness", } \\
\text { "Critical inquiry", "Critical } \\
\text { self-awareness", "Self } \\
\text { Reflective ability", } \\
\text { "Reflective learning", "Self- } \\
\text { Reflection", Reflectivity }\end{array}$ \\
\hline
\end{tabular}

The search identified 6968 potential articles. The lead reviewer, through screening of title, abstract, and then whole paper, refined results down to 26 using the inclusion criteria detailed in 
Table 2 and the refinement process illustrated in Figure 2. The McMaster critical review guidelines (Law et al. 1998) were used to ensure quality of the papers included. This guideline was chosen as it can be applied to a wide variety of methodologies, whilst providing a consistent grounding from which quality and subsequent inclusion/exclusion decisions can be made. Qualitative studies were included in the review when overall rigour (i.e. creditability, transferability, dependability and confirmability) was both justified and adequate as per the McMaster analysis form. Quality of quantitative studies was determined by design appropriateness, sampling method, data analysis and conclusions in keeping with results. Studies that did not clearly report or justify methods used were excluded from the final collection of studies in the review. Studies were also excluded if they only confirmed the value of reflection, a valuable though already established outcome. Authors MP and GN confirmed consistent use of the McMaster guidelines, with $100 \%$ consensus with ratings by the primary author from a selection $(n=6)$ of the included studies. This selection of six papers contained papers that were of borderline and of high quality, ensuring a range of quality standards was considered.

\section{Table 2. Inclusion criteria}

1. Based on an empirical research design

2. Included student participants from allied health (Health Education and Training Institute (HETI) n.d.), nursing, and medicine

3. Identified and explained the use of a reflective framework within a reflective activity; for example, a guide to use when completing a journal

4. Described outcomes related to the use of a reflective teaching strategy

\section{Results}

A summary of the papers included in this review utilising key elements that relate to the focus of the paper are illustrated in Table 3 . Headings listed along the horizontal axis include the reported aim of each study, the approach used to develop reflection, and the contextual factors reportedly used to assist in the process of reflective development. The use of contextual factors across all studies varied. To ensure consistency in analysis, contextual factors were considered to have been utilised if key words synonymous with each contextual factor were expressed in relation to the environment in which the reflective teaching strategy took place.

The dominant structural approach used to develop reflection was the Process approach (Table 3). This approach was used by 16 of the 26 papers. A further eight papers used the Vertical approach. Evidence for an emerging structural approach using a Vertical structure in a repeated, or Process manner to develop reflection was also found in one paper (Jensen and Joy 2005). Only $33 \%$ of papers included in this review made use of seminal theoretical understandings, for Mezirow (1990), Schön (1987), as a foundation to define the reflective depth of participants. Novel, or non-defined criteria to assess outcomes made up the majority of the included studies at $52 \%$. The remainder used rubrics based on previous literature. 
Figure 2. Refinement process of search results

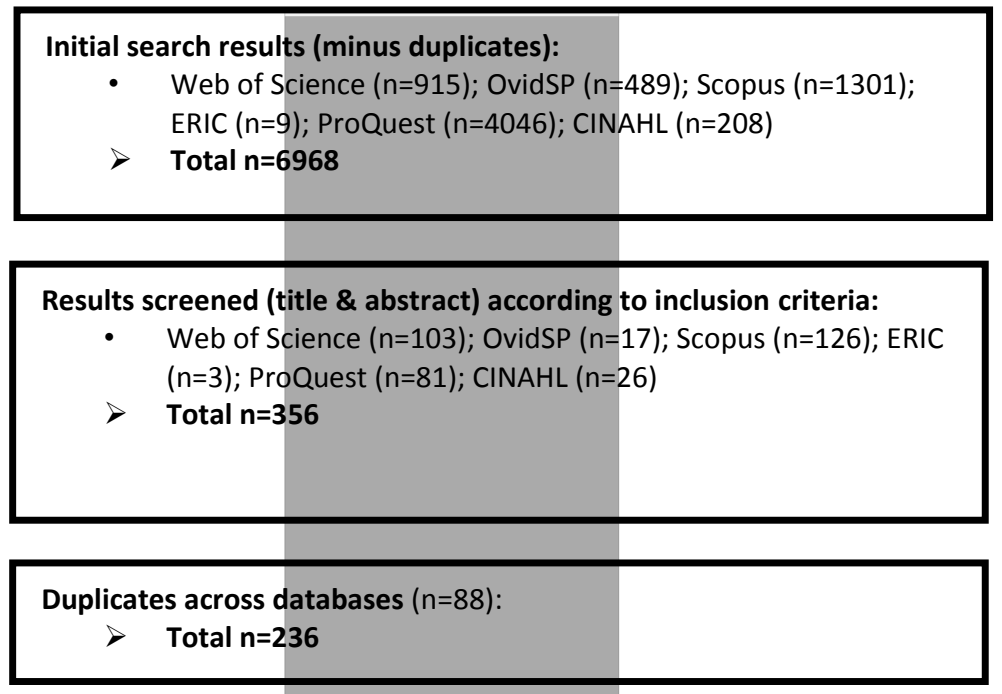

Results screened according to inclusion criteria:

- Papers discarded:

No empirical research design $(n=59)$

Did not report procedure for reflective framework and activity ( $n=34)$

Outcomes not related to the use of a reflective teaching strategy $(n=27)$

Total $n=28$

Reference mining conducted according to inclusion criteria $(n=7)$

$>$ Total $n=35$

Papers excluded per McMaster (Law et al. 1998) quality analysis $(n=6)$

- Discarded papers:

Poor procedural rigor $(n=2)$

Poor data collection $(n=2)$

Poor trustworthiness $(n=3)$

Total $n=29$

Papers excluded that only recognised value of reflection

- Excluded $(n=3)$

$>$ Total $n=26$

$>$ Total articles included in review $\mathrm{n}=\mathbf{2 6}$ 
The common theme running throughout this review is that of variation. This variation is demonstrated in the reported aims of each of the identified papers. These varying aims included investigation of the effect of timing of feedback on reflection(Dye et al. 2011); cultural competence associated with reflection (Lie et al. 2010); emotional intelligence (Harrison and Fopma-Loy 2010); and development of reflection (Aronson et al. 2012, lp et al. 2012, Makoul et al. 2010).An equally diverse range of analysis techniques were used to support these aims as illustrated by professional consensus (Makoul et al. 2010), qualitative methodologies including 'immersion-crystallization style' (Wald et al. 2009), and descriptive statistics (Aronson et al. 2012. Wald et al. 2009). The theme of variation is also demonstrated by the duration of interventions used to enhance or support reflection during clinical placements. Intervention duration ranged from one session (Lillyman, Gutteridge, and Berridge 2011) through to two years (Wald et al. 2009). Some studies only reported overall placement duration, rather than specific time set aside to support or teach reflection.

All studies reported positive outcomes from the implementation of reflective teaching strategies. Further exploration of these findings highlights the influence of repetition, indicating the more exposure a student had to a particular reflective strategy the greater the incidence of reflective elements appearing in practice (Kuiper, Murdock, and Grant 2010)and the greater students' movement along the reflective continuum (Tsang 2012, Wald et al. 2009). Conversely findings from Findlay, Dempsey, and Warren-Forward (2011) and Chirema (2007) demonstrate that critical reflection can also be achieved from a single exposure. This conflict in the evidence is further complicated by findings from Jenson and Joy (2005) who found a decrease in reflective elements over time in students' journaling. Aronson et al. (2011) and Wald et al. (2009) also report decreased engagement in the reflective process with reports of constraint from static reflective teaching strategies as time progressed (Table 3 ).

No clear pattern was found in respect to the number of, or type of contextual factors present and its influence on reported outcomes. The majority of the identified studies reported that students' reflection was enhanced from the use of reflective teaching strategies, despite variability in the number of contextual elements present. This is demonstrated by Aronson et al. (2012), Ip et al. (2012), and Tsang (2012) who incorporate three or four of Mann, Gordon, and MacLeod (2009) contextual factors. Conversely Lie et al. (2010), Levine, Kern, and Wright (2008), and Stark et al. (2006) incorporated one or two different factors, yet also reported enhanced reflective depth. Investigation of this conflict is challenging, as there is no common or high quality measurement tool presently used to allow comparison, nor is there a pattern evident in the literature for type of contextual factor and its impact on students' ability to reflect in practice. 
Table 3. Results

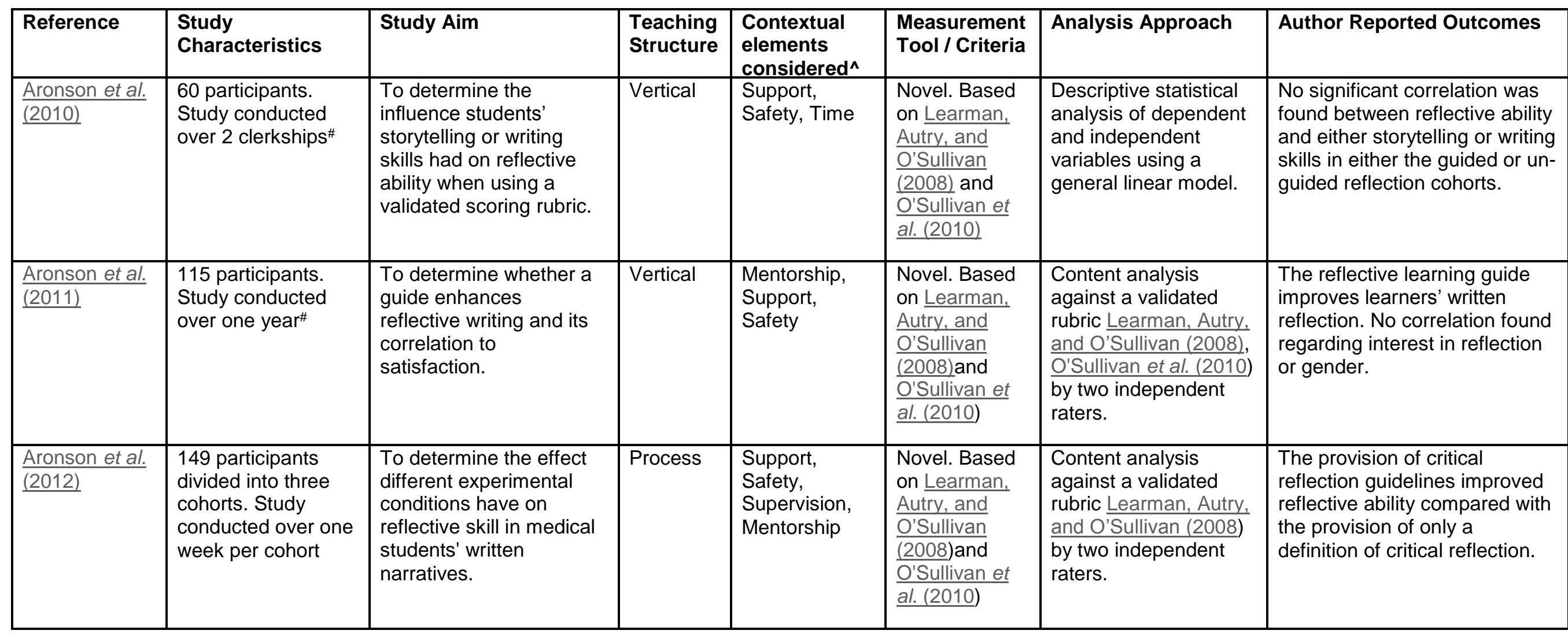




\begin{tabular}{|c|c|c|c|c|c|c|c|}
\hline Asselin (2011) & $\begin{array}{l}10 \text { participants. } \\
\text { Study conducted } \\
\text { over one semester\# }\end{array}$ & $\begin{array}{l}\text { To describe the } \\
\text { experience from } \\
\text { students' perspective of } \\
\text { using reflective teaching } \\
\text { strategies and how it } \\
\text { facilitated performance } \\
\text { change }\end{array}$ & Process & $\begin{array}{l}\text { Safety, } \\
\text { Support }\end{array}$ & $\begin{array}{l}\left(\frac{\text { Kim 1999) }}{\text { model of }}\right. \\
\text { reflection }\end{array}$ & $\begin{array}{l}\text { Qualitative } \\
\text { phenomenological } \\
\text { approach using } \\
\text { voluntary participants. }\end{array}$ & $\begin{array}{l}\text { The quality of students' } \\
\text { reflections improved with } \\
\text { greater exposure to reflective } \\
\text { teaching strategies. This in turn } \\
\text { facilitated performance } \\
\text { change. }\end{array}$ \\
\hline $\begin{array}{l}\text { Canniford and } \\
\text { Fox-Young } \\
\underline{(2015)}\end{array}$ & $\begin{array}{l}163 \text { participants. } \\
\text { Study conducted } \\
\text { over one semester" }\end{array}$ & $\begin{array}{l}\text { To evaluate the use of a } \\
\text { reflective learning } \\
\text { package with nursing } \\
\text { students. }\end{array}$ & Process & $\begin{array}{l}\text { Safety, } \\
\text { Support }\end{array}$ & $\begin{array}{l}\text { Lasater and } \\
\text { Nielsen (2009) }\end{array}$ & $\begin{array}{l}\text { The Lasater clinical } \\
\text { judgment rubric } \\
\text { (Lasater 2007) }\end{array}$ & $\begin{array}{l}\text { Students' self-rated } \\
\text { evaluations strongly agreed } \\
(76.3 \%) \text { that reflection had } \\
\text { value to them. }\end{array}$ \\
\hline $\begin{array}{l}\underline{\text { Chirema }} \\
\underline{(2007)}\end{array}$ & $\begin{array}{l}2 \text { participants. } \\
\text { Study conducted } \\
\text { over a one year\# } \\
\text { period }\end{array}$ & $\begin{array}{l}\text { To examine the use of } \\
\text { reflective journals in } \\
\text { post-graduate nursing } \\
\text { students to determine } \\
\text { level and extent of } \\
\text { reflection. }\end{array}$ & Vertical & $\begin{array}{l}\text { Safety, } \\
\text { Supervision }\end{array}$ & $\frac{\text { Wong et al. }}{(1995) \text { and) }}$ & $\begin{array}{l}\text { Qualitative content } \\
\text { analysis using the } \\
\text { process defined in } \\
\text { (Miles and Huberman } \\
\text { 1994) by two } \\
\text { independent raters. } \\
0.5-.0 .75 \text { agreement } \\
\text { reached. }\end{array}$ & $\begin{array}{l}\text { Two thirds of respondents } \\
\text { ( } \mathrm{n}=28 \text { ) illustrated varying levels } \\
\text { of reflection according to the } \\
\text { Wong et al. (1995) defined } \\
\text { criteria. Results indicate that } \\
\text { guided journals are a useful } \\
\text { tool to promote reflection. }\end{array}$ \\
\hline $\begin{array}{l}\frac{\text { Chretien, }}{\text { Goldman, and }} \\
\text { Faselis (2008) }\end{array}$ & $\begin{array}{l}91 \text { participants. } \\
\text { Study conducted } \\
\text { over a four week } \\
\text { period }\end{array}$ & $\begin{array}{l}\text { To promote reflection on } \\
\text { professional } \\
\text { development using a } \\
\text { novel approach. }\end{array}$ & Vertical & $\begin{array}{l}\text { Support, } \\
\text { Safety, } \\
\text { Mentorship }\end{array}$ & $\frac{\text { Mezirow }}{(1991)}$ & $\begin{array}{l}\text { Qualitative content } \\
\text { analysis by two raters } \\
\text { independently using a } \\
\text { modified version of the } \\
\text { Moustakas method } \\
\text { (Moustakas 1994) }\end{array}$ & $\begin{array}{l}\text { The reflection process assisted } \\
\text { students' educational } \\
\text { experience and the affective } \\
\text { components involved with this. } \\
169 \text { of } 177 \text { posts were defined } \\
\text { as reflective according to the } \\
\text { criteria. }\end{array}$ \\
\hline
\end{tabular}




\begin{tabular}{|c|c|c|c|c|c|c|c|}
\hline$\frac{\text { Dye et al. }}{\underline{(2011)}}$ & $\begin{array}{l}15 \text { participants. } \\
\text { Study conducted } \\
\text { over a } 16 \text { week } \\
\text { period }\end{array}$ & $\begin{array}{l}\text { To determine the effects } \\
\text { delayed or immediate } \\
\text { specific email feedback } \\
\text { had on physical therapy } \\
\text { students' journals. }\end{array}$ & Process & $\begin{array}{l}\text { Support, } \\
\text { Supervision, } \\
\text { Safety, } \\
\text { Mentorship }\end{array}$ & $\begin{array}{l}\text { Novel. Based } \\
\text { on Williams et } \\
\text { al. (2000) }\end{array}$ & $\begin{array}{l}\text { Qualitative content } \\
\text { analysis by two } \\
\text { independent raters for } \\
\text { consensus using the } \\
\text { criteria validated in } \\
\text { (Williams et al. 2000) }\end{array}$ & $\begin{array}{l}\text { No statistically significant } \\
\text { difference identified between } \\
\text { delayed or immediate feedback } \\
\text { type cohorts over the course of } \\
\text { investigation. }\end{array}$ \\
\hline $\begin{array}{l}\text { Findlay, } \\
\text { Dempsey, and } \\
\text { Warren- } \\
\underline{\text { Forward }} \\
\underline{\text { (2011) }}\end{array}$ & $\begin{array}{l}6 \text { participants. } \\
\text { Study conducted } \\
\text { over a four week } \\
\text { period }\end{array}$ & $\begin{array}{l}\text { To validate the } \\
\text { Newcastle Reflective } \\
\text { Inventories, and } \\
\text { Reflective Analysis Tool } \\
\text { to assess guided } \\
\text { reflective writing. }\end{array}$ & Vertical & Time, Support & $\begin{array}{l}\text { Boud, Keogh, } \\
\underline{\text { and Walker }} \\
\underline{(1985)}\end{array}$ & $\begin{array}{l}\text { Independent analysis } \\
\text { by two raters prior to } \\
\text { consensus using the } \\
\text { validated 'Deep } \\
\text { Analytic Newcastle } \\
\text { Reflective Analysis } \\
\text { Tool' (Findlay, } \\
\text { Dempsey, and } \\
\text { Warren-Forward 2011) }\end{array}$ & $\begin{array}{l}\text { A statistically significant } \\
\text { difference was found in the } \\
\text { level of reflection achieved in } \\
\text { free-form versus guided } \\
\text { journals. All participants in the } \\
\text { guided journal cohort } \\
\text { demonstrated critical reflection } \\
\text { per the defined criteria. }\end{array}$ \\
\hline $\begin{array}{l}\frac{\text { Harrison and }}{\text { Fopma-Loy }} \\
\text { (2010) }\end{array}$ & $\begin{array}{l}16 \text { participants. } \\
\text { Study conducted } \\
\text { over } 16 \text { weeks }\end{array}$ & $\begin{array}{l}\text { To test the effect ten } \\
\text { reflective journal prompts } \\
\text { had on nursing student } \\
\text { emotional intelligence. }\end{array}$ & Process & $\begin{array}{l}\text { Safety, } \\
\text { Support }\end{array}$ & Not defined & $\begin{array}{l}\text { Analysis completed } \\
\text { using author } \\
\text { consensus on selected } \\
\text { competencies from } \\
\text { (Goleman, Boyatzis, } \\
\text { and McKee 2001) } \\
\text { (Emotional Intelligence } \\
\text { Framework) }\end{array}$ & $\begin{array}{l}\text { Qualitative analysis using an } \\
\text { emotional intelligence } \\
\text { framework found the prompts } \\
\text { elicited reflective responses } \\
\text { across all targeted emotional } \\
\text { intelligence domains. }\end{array}$ \\
\hline $\begin{array}{l}\text { Hill, Davidson, } \\
\text { and } \\
\text { Theodoros } \\
\text { (2012) }\end{array}$ & $\begin{array}{l}52 \text { participants. } \\
\text { Study conducted } \\
\text { over one semester\# }\end{array}$ & $\begin{array}{l}\text { To describe the depth } \\
\text { and breadth of reflective } \\
\text { skills in speech-language } \\
\text { therapy (SLT) students' } \\
\text { structured journals. }\end{array}$ & Process & $\begin{array}{l}\text { Support, } \\
\text { Safety, } \\
\text { Supervision }\end{array}$ & $\begin{array}{l}\text { Schön (1987), } \\
\text { Bloom (1956), } \\
\text { and Mezirow } \\
\underline{(1990)}\end{array}$ & $\begin{array}{l}\text { Qualitative content } \\
\text { analysis as detailed in } \\
\text { Plack and Greenberg } \\
\underline{(2005)}\end{array}$ & $\begin{array}{l}\text { SLT students were shown that } \\
\text { they can reflect on their } \\
\text { experiences, with the majority } \\
\text { categorized as 'reflectors' } \\
(94 \%) \text { as per the defined } \\
\text { criteria. }\end{array}$ \\
\hline
\end{tabular}




\begin{tabular}{|c|c|c|c|c|c|c|c|}
\hline$\frac{\frac{\text { Hulsman, }}{\text { Harmsen, and }}}{\underline{\text { Fabriek (2009) }}}$ & $\begin{array}{l}304 \text { participants. } \\
\text { Study conducted } \\
\text { over one semester\# }\end{array}$ & $\begin{array}{l}\text { To develop a rating } \\
\text { criteria for the } \\
\text { assessment of students' } \\
\text { level of reflection. }\end{array}$ & Process & $\begin{array}{l}\text { Time, Safety, } \\
\text { Support, } \\
\text { Mentorship }\end{array}$ & $\begin{array}{l}\text { Novel. Based } \\
\text { on } \\
\text { investigation }\end{array}$ & $\begin{array}{l}\text { Assessment criteria } \\
\text { developed from } \\
\text { iterative process using } \\
20 \% \text { of data prior to } \\
\text { complete analysis and } \\
\text { author consensus. }\end{array}$ & $\begin{array}{l}\text { Four separate rating criteria } \\
\text { were identified during the } \\
\text { investigation. Using this criteria } \\
\text { nursing student level of } \\
\text { reflection was primarily at the } \\
\text { 'description' criteria. }\end{array}$ \\
\hline Ip et al. (2012) & $\begin{array}{l}38 \text { participants. } \\
\text { Study conducted } \\
\text { over a four week } \\
\text { period }\end{array}$ & $\begin{array}{l}\text { To evaluate the change } \\
\text { in levels of reflection pre } \\
\text { and post intervention. }\end{array}$ & Process & $\begin{array}{l}\text { Mentorship, } \\
\text { Safety, } \\
\text { Support, } \\
\text { Supervision }\end{array}$ & \begin{tabular}{|l} 
Wong et al. \\
$(1995)$
\end{tabular} & $\begin{array}{l}\text { Qualitative content } \\
\text { analysis as detailed in } \\
\text { Huberman and Miles } \\
\text { (2002) by two raters } \\
\text { independently. }\end{array}$ & $\begin{array}{l}\text { Statistical analysis identified } \\
73.7 \% \text { of participants } \\
\text { progressed from descriptive } \\
\text { reflectors to reflectors, whilst } \\
\text { another } 13.2 \% \text { were rated as } \\
\text { critical. Both percentages rose } \\
7.9 \% \text { and } 0 \% \text { respectively from } \\
\text { baseline. }\end{array}$ \\
\hline$\frac{\text { Jensen and }}{\text { Joy }(2005)}$ & $\begin{array}{l}20 \text { participants. } \\
\text { Study conducted } \\
\text { over a } 12 \text { week } \\
\text { period }\end{array}$ & $\begin{array}{l}\text { To measure the level of } \\
\text { reflection in nursing } \\
\text { student journals. }\end{array}$ & Process & Nil & \begin{tabular}{|l} 
Mezirow \\
$1981)$
\end{tabular} & $\begin{array}{l}\text { Qualitative content } \\
\text { analysis conducted } \\
\text { independently by two } \\
\text { raters using a reported } \\
\text { process. }\end{array}$ & $\begin{array}{l}18 \% \text { of participants achieved } \\
\text { critical reflection levels, } 40 \% \\
\text { achieved discriminate } \\
\text { reflection as per the defined } \\
\text { criteria. The investigation also } \\
\text { highlighted a gradual decrease } \\
\text { in reflective elements over time } \\
\text { (12 weeks). }\end{array}$ \\
\hline $\begin{array}{l}\frac{\text { Kuiper, }}{\text { Murdock, and }} \\
\text { Grant (2010) }\end{array}$ & $\begin{array}{l}26 \text { participants } \\
\text { divided into two } \\
\text { cohorts who } \\
\text { received either } 60 \\
\text { or } 120 \text { hours of } \\
\text { clinical opportunities }\end{array}$ & $\begin{array}{l}\text { To determine if an } \\
\text { increase in practicum } \\
\text { hours influences nursing } \\
\text { student clinical cognition } \\
\text { as assessed through } \\
\text { journals. }\end{array}$ & Process & $\begin{array}{l}\text { Supervision, } \\
\text { Safety, } \\
\text { Support }\end{array}$ & $\begin{array}{l}\text { Novel. Based } \\
\text { on reported } \\
\text { meta-cognitive } \\
\text { elements }\end{array}$ & $\begin{array}{l}\text { Qualitative content } \\
\text { analysis using } \\
\text { 'Retrospective Verbal } \\
\text { Protocol Analysis' } \\
\text { Kuusela. and Pallab } \\
\underline{(2000)} .\end{array}$ & $\begin{array}{l}\text { Qualitative narrative analysis } \\
\text { using a defined criteria found } \\
\text { that the } 120 \text { clinical hours } \\
\text { cohort demonstrated a higher } \\
\text { incidence of meta-cognitive } \\
\text { strategies when compared to } \\
\text { the } 60 \text {-hour cohort. }\end{array}$ \\
\hline
\end{tabular}




\begin{tabular}{|c|c|c|c|c|c|c|c|}
\hline $\begin{array}{l}\text { Levine, Kern, } \\
\text { and Wright } \\
\text { (2008) }\end{array}$ & $\begin{array}{l}32 \text { participants. } \\
\text { Study conducted } \\
\text { over a one year" } \\
\text { period }\end{array}$ & $\begin{array}{l}\text { To determine the } \\
\text { influence of prompting on } \\
\text { reflection. }\end{array}$ & Process & $\begin{array}{l}\text { Safety, } \\
\text { Support }\end{array}$ & $\begin{array}{l}\text { Novel. Based } \\
\text { on definition } \\
\text { by Bolton } \\
(2010)\end{array}$ & $\begin{array}{l}\text { Qualitative analysis } \\
\text { using the 'editing } \\
\text { analysis style' } \\
\text { conducted } \\
\text { independently by two } \\
\text { authors. }\end{array}$ & $\begin{array}{l}\text { Iterative qualitative approach } \\
\text { identified that prompting lead } \\
\text { to deeper reflection in } 19 / 20 \\
\text { participants. }\end{array}$ \\
\hline $\begin{array}{l}\text { Lie et al. } \\
\text { (2010) }\end{array}$ & $\begin{array}{l}188 \text { participants. } \\
\text { Study conducted } \\
\text { over a four week } \\
\text { period }\end{array}$ & $\begin{array}{l}\text { To enhance students } \\
\text { cultural competence } \\
\text { using guided reflective } \\
\text { narratives. }\end{array}$ & Process & Safety & Not defined & $\begin{array}{l}\text { Descriptive statistical } \\
\text { analysis of Likert-scale } \\
\text { student responses, } \\
\text { and author consensus } \\
\text { on qualitative themes }\end{array}$ & $\begin{array}{l}\text { Qualitative thematic analysis } \\
\text { identified seven primary } \\
\text { themes that students explored } \\
\text { to come to novel } \\
\text { understandings during guided } \\
\text { narratives. }\end{array}$ \\
\hline 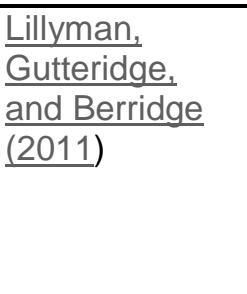 & $\begin{array}{l}41 \text { participants. } \\
\text { Study evaluated } \\
\text { post one } \\
\text { intervention }\end{array}$ & $\begin{array}{l}\text { To determine the effect } \\
\text { of storyboarding on } \\
\text { student nurse level of } \\
\text { reflection. }\end{array}$ & Vertical & $\begin{array}{l}\text { Safety, } \\
\text { Support, } \\
\text { Mentorship, } \\
\text { Time, } \\
\text { Supervision }\end{array}$ & Not defined & $\begin{array}{l}\text { Novel qualitative } \\
\text { questionnaire based } \\
\text { on pilot study findings } \\
\text { and aspects of } \\
\text { teaching and learning. }\end{array}$ & $\begin{array}{l}\text { Qualitative content analysis } \\
\text { suggested that a high } \\
\text { proportion of students } \\
\text { achieved critical thinking and } \\
\text { deeper reflection when using } \\
\text { the reported storyboarding } \\
\text { technique. }\end{array}$ \\
\hline $\begin{array}{l}\text { Makoul et al. } \\
\text { (2010) }\end{array}$ & $\begin{array}{l}315 \text { participants. } \\
\text { Study conducted } \\
\text { over a four month } \\
\text { period }\end{array}$ & $\begin{array}{l}\text { What effect an online } \\
\text { forum with structured } \\
\text { templates had on } \\
\text { reflection. }\end{array}$ & Vertical & $\begin{array}{l}\text { Safety, } \\
\text { Support, Time }\end{array}$ & Not defined & $\begin{array}{l}\text { Qualitative content } \\
\text { analysis using a } \\
\text { reported process by } \\
\text { two raters, then author } \\
\text { consensus. }\end{array}$ & $\begin{array}{l}\text { Structured templates } \\
\text { encouraged reflection and } \\
\text { dialogue about difficult } \\
\text { conversations. }\end{array}$ \\
\hline $\begin{array}{l}\frac{\text { Plack, Dunfee, }}{\text { and Rindflesch }} \\
\underline{\text { (2008) }}\end{array}$ & $\begin{array}{l}7 \text { participants. } \\
\text { Study conducted } \\
\text { over a four week } \\
\text { period }\end{array}$ & $\begin{array}{l}\text { To determine the effect } \\
\text { virtual action learning } \\
\text { had on reflection and } \\
\text { cognition across two } \\
\text { cohorts. }\end{array}$ & Process & $\begin{array}{l}\text { Time, Support, } \\
\text { Safety, } \\
\text { Mentorship }\end{array}$ & $\begin{array}{l}\text { Schön (1987), } \\
\text { Bloom (1956), } \\
\text { and Mezirow } \\
(1990)\end{array}$ & $\begin{array}{l}\text { Qualitative content } \\
\text { analysis by two raters. } \\
\text { Consensus confirmed } \\
\text { by a third independent } \\
\text { rater to confirm } \\
\text { creditability. }\end{array}$ & $\begin{array}{l}\text { No statistically significant } \\
\text { difference was reported } \\
\text { between the two cohorts } \\
\text { (mentor facilitated \& peer } \\
\text { facilitated) regarding timing of } \\
\text { reflection or level of reflection. }\end{array}$ \\
\hline
\end{tabular}




\begin{tabular}{|c|c|c|c|c|c|c|c|}
\hline $\begin{array}{l}\text { Stark et al. } \\
\underline{(2006)}\end{array}$ & $\begin{array}{l}250 \text { participants. } \\
\text { Study conducted } \\
\text { over three separate } \\
\text { periods, each } \\
\text { lasting three days }\end{array}$ & $\begin{array}{l}\text { To determine the } \\
\text { outcomes of combined } \\
\text { critical incident technique } \\
\text { on guided reflection } \\
\text { using written narratives. }\end{array}$ & Vertical & $\begin{array}{l}\text { Supervision, } \\
\text { Safety }\end{array}$ & Novel & $\begin{array}{l}\text { Qualitative content } \\
\text { analysis using a } \\
\text { constant comparative } \\
\text { approach, which was } \\
\text { independently coded } \\
\text { to }>80 \% \text {. }\end{array}$ & $\begin{array}{l}\text { Thematic content analysis } \\
\text { identified five primary themes } \\
\text { which students expressed } \\
\text { during guided reflection } \\
\text { (communication, } \\
\text { professionalism, team work, } \\
\text { organisation of care, \& student } \\
\text { learning issues). All submitted } \\
\text { narratives ( } n=238 \text { ), bar two, } \\
\text { achieved 'some reflective } \\
\text { capacity'. }\end{array}$ \\
\hline $\begin{array}{l}\text { Thomas and } \\
\text { Goldberg } \\
\underline{\text { (2007) }}\end{array}$ & $\begin{array}{l}59 \text { participants. } \\
\text { Study conducted } \\
\text { over a four week } \\
\text { period }\end{array}$ & $\begin{array}{l}\text { To determine the effect } \\
\text { guided reflection using } \\
\text { PDA prompts has on } \\
\text { medical student } \\
\text { reflection. }\end{array}$ & Process & $\begin{array}{l}\text { Time, } \\
\text { Supervision, } \\
\text { Safety, } \\
\text { Mentorship, } \\
\text { Support }\end{array}$ & $\begin{array}{l}\text { Correlated to } \\
\text { reported meta- } \\
\text { cognitive } \\
\text { elements }\end{array}$ & $\begin{array}{l}\text { Qualitative thematic } \\
\text { analysis using a } \\
\text { reported process. }\end{array}$ & $\begin{array}{l}\text { Statistically significant } \\
\text { correlations were illustrated } \\
\text { between meta-cognitive } \\
\text { process use relating to } \\
\text { diagnostic thinking and } \\
\text { therapeutic observations, when } \\
\text { assessed using data obtained } \\
\text { from student electronic entries. }\end{array}$ \\
\hline Tsang (2012) & $\begin{array}{l}17 \text { participants. } \\
\text { Study conducted } \\
\text { over a one year\# } \\
\text { period }\end{array}$ & $\begin{array}{l}\text { To determine the levels } \\
\text { of reflection shown by } \\
\text { oral health students. }\end{array}$ & Process & $\begin{array}{l}\text { Support, } \\
\text { Safety, } \\
\text { Mentorship }\end{array}$ & $\begin{array}{l}\frac{\text { Boud, Keogh, }}{\text { and Walker }} \\
\frac{(1985) \text { and }}{\text { Mezirow }} \\
\frac{(1991)}{}\end{array}$ & $\begin{array}{l}\text { Qualitative thematic } \\
\text { analysis using } \\
\text { Leximancer } \\
\text { software. }\end{array}$ & $\begin{array}{l}\text { Thematic analysis indicated } \\
\text { students increased the critical } \\
\text { components of reflection over } \\
\text { the course of investigations. } \\
26 \% \text { illustrated the highest } \\
\text { level, whilst the majority ( } 58 \% \text { ) } \\
\text { illustrated the third level } \\
\text { (relating). }\end{array}$ \\
\hline
\end{tabular}




\begin{tabular}{|c|c|c|c|c|c|c|c|}
\hline$\frac{\text { Wald et al. }}{(2009)}$ & $\begin{array}{l}8 \text { participants. } \\
\text { Study conducted } \\
\text { over a two year\# } \\
\text { period }\end{array}$ & $\begin{array}{l}\text { To determine the effect } \\
\text { of guided reflective } \\
\text { writing and individualized } \\
\text { feedback on reflection. }\end{array}$ & Process & $\begin{array}{l}\text { Safety, } \\
\text { Support, } \\
\text { Mentorship, } \\
\text { Time, } \\
\text { Supervision }\end{array}$ & Not defined & $\begin{array}{l}\text { Qualitative content } \\
\text { analysis using an } \\
\text { independent } \\
\text { 'immersion- } \\
\text { crystallization' style. }\end{array}$ & $\begin{array}{l}\text { Qualitative content analysis } \\
\text { found that the guided reflection } \\
\text { approach with individualised } \\
\text { feedback promoted reflection } \\
\text { and professionalism as defined } \\
\text { within the context of this study. }\end{array}$ \\
\hline $\begin{array}{l}\text { Walker et al. } \\
\underline{(2013)}\end{array}$ & $\begin{array}{l}89 \text { participants. } \\
\text { Study conducted } \\
\text { over a } 12 \text { week } \\
\text { period }\end{array}$ & $\begin{array}{l}\text { The effect a learning } \\
\text { circle strategy has on } \\
\text { practice and the learning } \\
\text { environment. }\end{array}$ & Vertical & $\begin{array}{l}\text { Time, Support, } \\
\text { Safety, } \\
\text { Supervision }\end{array}$ & Not defined & $\begin{array}{l}\text { Qualitative content } \\
\text { analysis using a } \\
\text { reported process by } \\
\text { two raters. }\end{array}$ & $\begin{array}{l}\text { The structured learning circles } \\
\text { technique facilitated reflection } \\
\text { on difficult issues and topics } \\
\text { that assisted to increase } \\
\text { awareness to alternative } \\
\text { methods. }\end{array}$ \\
\hline $\begin{array}{l}\text { Wright and } \\
\text { Lundy (2012) }\end{array}$ & $\begin{array}{l}12 \text { participants. } \\
\text { Study conducted } \\
\text { over } 6 \text { days }\end{array}$ & $\begin{array}{l}\text { To assess the } \\
\text { development of reflective } \\
\text { thinking in allied health } \\
\text { students from a } \\
\text { collaborative blog. }\end{array}$ & Process & $\begin{array}{l}\text { Time, Support, } \\
\text { Safety }\end{array}$ & $\begin{array}{l}\frac{\text { Boud, Keogh, }}{\text { and Walker }} \\
\frac{(1985) \text { and }}{\text { Mezirow }} \\
\text { (1981) }\end{array}$ & $\begin{array}{l}\text { Qualitative content } \\
\text { analysis conducted by } \\
\text { two raters } \\
\text { independently. }\end{array}$ & $\begin{array}{l}\text { Repeated blogging using a } \\
\text { guiding structure increased the } \\
\text { incidence of Boud's reflective } \\
\text { elements, with 'deeper' } \\
\text { elements demonstrated in the } \\
\text { latter half of the investigation. }\end{array}$ \\
\hline
\end{tabular}

^ Mann, Gordon, and MacLeod (2009) (Contextual elements including mentorship, time to reflect, supervision, support, and a safe environment benefit the practice of reflection).

\#Exact study duration not explicitly stated. Study duration referred to in terms of semester, or year length. 


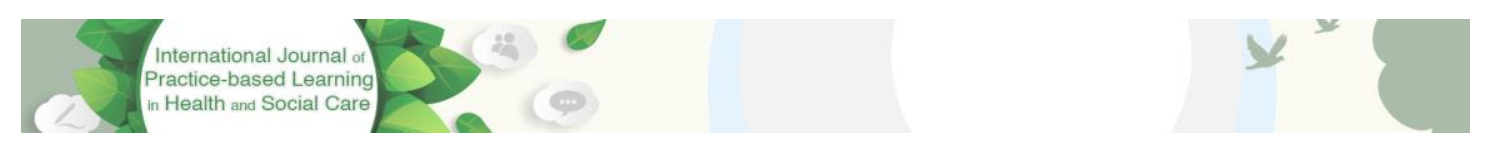

International Journal of Practice-based Learning in Health and Social Care Vol. 4 No 1 July 2016, pages 55-77

\section{Discussion}

The foci of this review are explored in this section using data obtained from analysis of the included studies. Positive findings, gaps, and inconsistencies are discussed with a view to supporting translation of reflective teaching strategies into practice.

\section{What evidence is there to support the use of reflective teaching strategies in professional healthcare clinical education?}

The identified papers use a range of evidence to support the practice of using reflective teaching strategies during placements with healthcare students. Investigations have been undertaken into students' perceptions of the worth of reflection (Canniford and Fox-Young 2015), the change in depth of reflection demonstrated over time (Dye et al. 2011, Ip et al. 2012, Levine, Kern, and Wright 2008, Wright and Lundy 2012), the effect of various mediums (for example, electronic, written narrative, verbal discourse), the influence on meta-cognition (Thomas and Goldberg 2007), professionalism (Wald et al. 2009), and what was reflected upon (Lie et al. 2010, Makoul et al. 2010, Walker et al. 2013). This diversity of evidence demonstrates the breadth of outcomes possible, and the potential influence reflective teaching strategies may have when used judiciously to support learner reflection whilst on placement.

This variety in evidence is extended through to the theoretical underpinnings of the identified studies. This is understandable given the range of professions represented in reviewed studies. Each profession is seen to have a preference for a theoretical basis on to which the evidence was developed. Nursing for example, which provided the majority of papers included in this review tends to use the work of Mezirow $(1990,1991)$ and subsequent work by Wong et al. (1995) that draws from Mezirow. The allied and oral health studies incorporate multiple theoretical underpinnings (Hill, Davidson, and Theodoros 2012, Plack, Dunfee, and Rindflesch 2008, Wright and Lundy 2012). These studies use combinations of Bloom (1956), Boud, Keogh, and Walker (1985), Mezirow (1990, 1991), and Schön (1987) in an effort to build on reflective learning from an established foundation. This grouping of nursing, allied, and oral health is juxtaposed with the included medical studies. This later cohort uses theories that have been developed from within the profession, for example that developed by Epstein (1999). This context-specific foundation allows unique adaptations that may assist delivery within a specific setting. However, it also has potential to narrow the perspective (Hulsman, Harmsen, and Fabriek 2009, Stark et al. 2006), or limit potential gains made from the application of reflective teaching strategies in isolation when compared to a strategy built upon clearly stated theoretical foundations that incorporates affective, cognitive, and meta-cognitive processes.

Generalising findings that reflective teaching strategies positively influence reflection must be done with caution because of the quality of the evidence upon which these findings have originated. As demonstrated above, the majority of evidence does not use a defined criterion. If it is present, this criterion is reported upon using descriptors that suit the context (for example Lillyman, Gutteridge, and Berridge 2011) rather than the cognitive or meta-cognitive elements shaping the reflection. This in turn limits translation of findings to other contexts.

Evidence from this review suggests that deepening of reflection can result from repetitive exposure to reflective teaching strategies. This is likely a result of increased familiarity with, or skill in, the process of reflecting when using a specific strategy. Analysis of the evidence also highlights the tendency for the majority of participants to reach the conceptual middle of the depth of reflection continuum, whilst comparatively small numbers achieve a critical depth. This trend occurs regardless of criterion or strategy used. Determining when, and which, students to apply either structural approach with appears the more apt question. It is logical to posit that students less familiar, or less adept at developing reflection are more suited to a Process approach that allows gradual introduction to both the concepts and application, whilst those who learn a strategy quickly, or achieve critical depth of reflection, are likely more suited to Vertical 
approaches that can be applied to critical incidents rather than the more gradual Process approach. This transition between approaches, dependent on student performance, may assist in maintaining engagement in the reflective process long term.

\section{What, if any measurement tools have been used in current research?}

A measurement tool would ideally be based on theory, be reliable and valid, and demonstrate not only the depth of reflection a student is demonstrating, but also the change in depth following repeated exposure to a reflective teaching strategy. There are tools already available in the literature that reflect this; for example, Sobral's 'Reflective Learning Scale (Sobral 2005) that captures cognitive components and self-regulation strategies. The Kember and Leung reflection questionnaire (Lethbridge et al. 2013) uses Mezirow's theoretical foundations to measure depth of reflective thinking. The Groningen Reflection Ability Scale (GRAS) (Andersen et al. 2014, Aukes et al. 2007) has been reported to yield valid and reliable measurement of personal reflection. Finally the 'REFLECT' measurement tool (Wald et al. 2012) measures reflective capacity according to four defined criteria. However, none of these tools has been incorporated into the reviewed studies despite the gains in research quality that can come from using valid and reliable measurement.

The failure of the majority of studies to use valid and reliable measurement tools results in considerable variation in the reported analysis strategies. This variation is demonstrated by the introduction of novel analysis practices. Canniford and Fox-Young (2015) used student perception, Dye et al. (2011), Chretien, Goldman and Faselis (2008) and lp et al. (2012) each used different qualitative methodologies, and Aronson et al. (2010) used a marking rubric. In addition to these analysis strategies, a majority of the papers in this review have used consensus methods where reflective elements are first defined then confirmed by independent raters during analysis (Harrison and Fopma-Loy 2010, Lillyman, Gutteridge, and Berridge 2011, Makoul et al. 2010). These latter-mentioned studies do not consistently outline the manner in which reliability and validity is determined. Therefore, confidence in these results can be questioned. Conversely, the professional consensus methodology reported in Jenson and Joy (2005), Levine, Kern, and Wright (2008), and Wald et al. (2009) used clear decision-making guidelines and a defined classification system that assists validity and reliability. This variation in analysis strategies, in addition to the inconsistencies of defined reflective criteria to which outcomes are applied, throws doubt on the validity of the positive outcomes reported from assisting students to reflect.

\section{How is current evidence integrating the use of contextual factors to support reflection?}

The study by Mann, Gordon, and MacLeod (2009) outlined the role that context has on the development of reflection. To ensure optimal outcomes in the use of a reflective teaching strategy, five contextual factors (time, mentorship, supervision, support, and safety) were identified by Mann, Gordon, and MacLeod (2009) as influential in the development and practice of reflection in the placement context.

No clear pattern was found in this review in respect to the presence of contextual factors and influence on reported outcomes. The majority of studies reported that reflective teaching strategies positively influence outcomes in assisting students to reflect regardless of the number of contextual factors incorporated. This finding is likely a consequence of the variable methodologies and measurement practices used in the included studies, rather than the impact per se of the factors. The utility of contextual factors has already been established by Mann, Gordon, and MacLeod (2009). It is likely that more explicit consideration of these factors, and the influence they can have on reflection in future research, will assist researchers and educators alike in regard to how to integrate these into practice. 


\section{Conclusions}

Current research suggests that reflective teaching strategies may progress healthcare students along a reflective continuum. The diversity in the quality of the evidence, the utility of the analysis strategies, and the integration of contextual factors that can assist the development of reflection remain inconsistently applied despite the foundations laid by Mann, Gordon, and MacLeod (2009). Interestingly, irrespective of the number of contextual factors, all identified papers reported that students either progressed along a reflective continuum towards a critical depth of reflection, or displayed improvements to meta/cognitive elements (e.g. self-awareness) that underpin critical reflection. No paper reported negative outcomes, which may be the results of poor research design or data analysis, or bias in data selection for publication.

A limitation of this review paper could be considered to be the foci on approaches used to measure outcomes and influences of the teaching of reflection during healthcare students' clinical placement, rather than specifics of teaching strategies, student behavior change and/or improved patient outcomes associated with reflective practice. The latter being the primary goal of critical reflection in healthcare settings by clinicians. Sound measurement practices in reflection will provide a basis for analysis of behavior change, patient outcomes and a range of other areas that reflection may influence. This review deliberately focused on this foundation rather than explore teaching strategies in order to collate information pertaining to a vital aspect of holistic understanding of reflection in the placement setting. Moreover, until valid and reliable measures are routinely used, exploration of improved patient outcomes is unlikely to result in definitive findings.

This systematised review of the evidence between 2005 and 2015 has identified that, despite publication of valid and reliable measurement tools, these appear to be under-utilised in published studies. These tools may assist the development of reflection through objective measurement, resulting in modification of reflective teaching structure to suit individual student learning proficiency. We suggest that future studies into the use of reflective teaching strategies in healthcare placement education investigate the adaptive use of structural approaches dependent on objective measurement of student reflections, with consideration of appropriate contextual factors. We hypothesize this will facilitate student movement along the reflective continuum, whilst managing ongoing engagement and learner self-regulation in the use of reflective strategies to encourage their own future life-long learning. 


\section{References}

Andersen, N. B., O'Neill, L., Gormsen, L. K., Hvidberg, L., and Morcke, A. M. (2014) 'A validation study of the psychometric properties of the Groningen Reflection Ability Scale'. BMC Medical Education 14 (1), 214. doi: 10.1186/1472-6920-14-214

Aronson, L., Niehaus, B., DeVries, C. D., Siegel, J. R., and O'Sullivan, P. S. (2010) 'Do writing and storytelling skill influence assessment of reflective ability in medical students' written reflections? Academic Medicine 85 (10), S29-S32.

doi:10.1097/ACM.0b013e3181ed3aa7

Aronson, L., Niehaus, B., Hill-Sakurai, L., Lai, C., and O'Sullivan, P. S. (2012) 'A comparison of two methods of teaching reflective ability in Year 3 medical students'. Medical Education 46 (8), 807-814. doi: 10.1111/i.1365-2923.2012.04299.x

Aronson, L., Niehaus, B., Lindow, J., Robertson, P. A., and O'Sullivan, P. S. (2011) 'Development and pilot testing of a reflective learning guide for medical education'. Medical Teacher 33 (10), e515-e521. doi: 10.3109/0142159x.2011.599894

Asselin, M. E. (2011) 'Using reflection strategies to link course knowledge to clinical practice: The RN-to-BSN student experience'. Journal of Nursing Education 50 (3), 125-133. doi:10.3928/01484834-20101230-08

Aukes, L. C., Geertsma, J., Cohen-Schotanus, J., Zwierstra, R. P., and Slaets, J. P. (2007) 'The development of a scale to measure personal reflection in medical practice and education'. Medical Teacher 29 (2-3), 177-182. doi:10.1080/01421590701299272

Beylefeld, A. A., Nena, K. D., and Prinsloo, E. A. (2005) 'Influence of community experiences on first-year medical students' reflective writing'. Medical Teacher 27 (2), 150-154. doi:org/10.1080/01421590400029590

Bloom, B. S. (ed.) (1956) Taxonomy of Educational Objectives: The Classification of Educational Goals. Handbook I: Cognitive Domain. New York: David McKay Company

Bolton, G. (2010) Reflective Practice: Writing and Professional Development (3rd edn.). London: Sage

Boud, D., Keogh, R., and Walker, D. (1985) Reflection: Turning Experience into Learning Abingdon, UK: Routledge

Canniford, L. J. and Fox-Young, S. (2015) 'Learning and assessing competence in reflective practice: Student evaluation of the relative value of aspects of an integrated, interactive reflective practice syllabus'. Collegian 22 (3), 291-297. doi:org/10.1016/i.colegn.2014.04.003

Chirema, K. D. (2007) 'The use of reflective journals in the promotion of reflection and learning in post-registration nursing students'. Nurse Education Today 27 (3), 192-202. doi:org/10.1016/i.nedt.2006.04.007

Chretien, K., Goldman, E., and Faselis, C. (2008) 'The reflective writing class blog: Using technology to promote reflection and professional development'. Journal of General Internal Medicine 23 (12), 2066-2070. doi: org/10.1007/s11606-008-0796-5

Donovan, M. O. (2007) 'Implementing reflection: Insights from pre-registration mental health students'. Nurse Education Today 27 (6), 610-616. doi:org/10.1016/i.nedt.2006.09.001 
Driessen, E., Tartwijk, J. v., and Dornan, T. (2008) 'The self critical doctor: Helping students become more reflective'. BMJ (CR)-print 336 (7648), 827.

doi:org/10.1136/bmj.39503.608032.ad

Dye, D., Scott, K. W., Ostrom, L., Devine, N., and Leight, J. (2011) 'The effect of specific feedback on critical reflection of physical therapy students during internships'. Journal of Adult Education 40 (2), 9-18.

Epstein, R. M. (1999) 'Mindful practice'. JAMA 282 (9), 833-839. doi:org/10.1001/jama.282.9.833

Findlay, N., Dempsey, S. E., and Warren-Forward, H. M. (2011) 'Development and validation of reflective inventories: assisting radiation therapists with reflective practice'. Journal of Radiotherapy in Practice 10 (1), 3-12. doi: org/10.1017/S1460396910000142

Goleman, D., Boyatzis, R., and McKee, A. (2001) 'Primal leadership: The Hidden driver of great performance'. Harvard Business Review 79 (11), 42-51.

Gordon, J. (2003) 'Assessing students' personal and professional development using portfolios and interviews'. Medical Education 37 (4), 335-340. doi:org/10.1046/j.13652923.2003.01475.x

Grant, M. J. and Booth, A. (2009) 'A typology of reviews: An analysis of 14 review types and associated methodologies'. Health Information and Libraries Journal 26 (2), 91-108. doi:org/10.1111/j.1471-1842.2009.00848.x

Harrison, P. A. and Fopma-Loy, J. L. (2010) 'Reflective journal prompts: A vehicle for stimulating emotional competence in nursing'. Journal of Nursing Education 49 (11), 644-652. doi:10.3928/01484834-20100730-07

Health Education and Training Institute (HETI) (n.d.) Allied health professionals in NSW health [online]. Retrieved from http://www.heti.nsw.gov.au/Allied-Health/Allied-HealthProfessions-in-NSW-Health/ [30 June 2016]

Hill, A. E., Davidson, B. J., and Theodoros, D. G. (2012) 'Reflections on clinical learning in novice speech-language therapy students'. International Journal of Language \& Communication Disorders 47 (4), 413-426. doi: 10.1111/j.1460-6984.2012.00154.x

Huberman, A. M. and Miles, M. B. (eds.) (2002) The Qualitative Researcher's Companion. Thousand Oaks, CA: Sage

Hulsman, R. L., Harmsen, A. B., and Fabriek, M. (2009) 'Reflective teaching of medical communication skills with DiViDU: Assessing the level of student reflection on recorded consultations with simulated patients'. Patient Education and Counseling 74 (2), 142149. doi: org/10.1016/i.pec.2008.10.009

Ip, W. Y., Lui, M. H., Chien, W. T., Lee, I. F., Lam, L. W., and Lee, D. (2012) 'Promoting selfreflection in clinical practice among Chinese nursing undergraduates in Hong Kong'. Contemporary Nurse 41 (2), 253-262. doi: 10.5172/conu.2012.41.2.253

Jensen, S. K. and Joy, C. (2005) 'Exploring a model to evaluate levels of reflection in baccalaureate nursing students' journals'. Journal of Nursing Education 44 (3), 139-142

Kim, H. S. (1999) 'Critical reflective inquiry for knowledge development in nursing practice'. Journal of Advanced Nursing 29 (5), 1205-1212. doi:10.1046/j.13652648.1999.01005.x 
Kleinheksel, A. J. (2014) 'Transformative learning through virtual patient simulations: Predicting critical student reflections'. Clinical Simulation in Nursing 10 (6), e301-e308. doi:10.1016/j.ecns.2014.02.001

Kuiper, R., Murdock, N., and Grant, N. (2010) 'Thinking strategies of baccalaureate nursing students prompted by self-regulated learning strategies'. Journal of Nursing Education 49 (8), 429-436. doi:10.3928/01484834-20100430-01

Kuusela, H. and Pallab, P. (2000) 'A comparison of concurrent and retrospective verbal protocol analysis'. The American Journal of Psychology 113 (3), 387-404

Lasater, K. (2007) 'Clinical judgment development: Using simulation to create an assessment rubric'. Journal of Nursing Education 46 (11) [online]

http://www.healio.com/journals/jne/2007-11-46-11/\%7Baaf1d95e-dd62-4be6-81b8f16dcfb10cca\%7D/clinical-judgment-development-using-simulation-to-create-anassessment-rubric

Lasater, K. and Nielsen, A. (2009) 'Reflective journaling for clinical judgment development and evaluation'. Journal of Nursing Education 48 (1), 40-44. doi:10.3928/01484834$\underline{\text { 20090101-06 }}$

Law, M., Stewart, D., Letts, L., Pollock, N., Bosch, J., and Westmorland, M. (1998) Guidelines for Critical Review of Qualitative Studies. [unpublished manuscript] Ontario, Canada: McMaster University Occupational Therapy Evidence-Based Practice Research Group

Learman, L. A., Autry, A. M. and O'Sullivan, P. (2008) 'Reliability and validity of reflection exercises for obstetrics and gynecology residents'. American Journal of Obstetrics \& Gynecology 198 (4), 461. e1461. e10. doi:10.1016/j.ajog.2007.12.021

Lethbridge, K., Andrusyszyn, M.-A., Iwasiw, C., Laschinger, H. K., and Fernando, R. (2013) 'Assessing the psychometric properties of Kember and Leung's Reflection Questionnaire'. Assessment \& Evaluation in Higher Education 38 (3), 303-325. doi:10.1080/02602938.2011.630977

Levine, R. B., Kern, D. E., and Wright, S. M. (2008) 'The impact of prompted narrative writing during internship on reflective practice: A qualitative study'. Advances in Health Sciences Education 13 (5), 723-733. doi: 10.1007/s10459-007-9079-x

Lie, D., Shapiro, J., Cohn, F., and Najm, W. (2010) 'Reflective practice enriches clerkship students' cross-cultural experiences'. Journal of General Internal Medicine 25 (2), 119125. doi:10.1007/s11606-009-1205-4

Lillyman, S., Gutteridge, R. and Berridge, P. (2011) 'Using a storyboarding technique in the classroom to address end of life experiences in practice and engage student nurses in deeper reflection'. Nurse Education in Practice 11 (3), 179-185. doi:10.1016/i.nepr.2010.08.006

Makoul, G., Zick, A. B., Aakhus, M., Neely, K. J., and Roemer, P. E. (2010) 'Using an online forum to encourage reflection about difficult conversations in medicine'. Patient Education and Counseling 79 (1), 83-86. doi:10.1016/i.pec.2009.07.027

Mamede, S. and Schmidt, H. G. (2004) 'The structure of reflective practice in medicine'. Medical Education 38 (12), 1302-1308. doi: 10.1111/j.1365-2929.2004.01917.x 
Mamede, S., van Gog, T., van den Berge, K., Rikers, R. M., van Saase, J. L., van Guldener, C., and Schmidt, H. G. (2010) 'Effect of availability bias and reflective reasoning on diagnostic accuracy among internal medicine residents'. JAMA 304 (11), 1198-1203. doi: org/10.1001/jama.2010.1276

Mann, K., Gordon, J., and MacLeod, A. (2009) 'Reflection and reflective practice in health professions education: A systematic review'. Advances in Health Sciences Education 14 (4), 595-621. doi: 10.1007/s10459-007-9090-2

Mezirow, J. (1981) A critical theory of adult learning and education. Adult Education Quarterly 32 (1), 3-24. doi: 10.1177/074171368103200101

Mezirow, J. (1990) 'How critical reflection triggers transformative learning'. In Fostering Critical Reflection in Adulthood: A Guide to Transformative and Emancipatory Learning ed. by Mezirow, J. and Associates. San Francisco: Jossey-Bass, 1-20.

Mezirow, J. (1991) Transformative Dimensions of Adult Learning. San Francisco: Jossey-Bass.

Miles, M. B. and Huberman, A. M. (1994) Qualitative data analysis: An expanded sourcebook 2nd edn. Thousand Oaks: Sage

Moustakas, C. (1994) Phenomenological Research Methods. Thousand Oaks, CA: Sage

O'Sullivan, P., Aronson, L., Chittenden, E., Niehaus, B., and Learman, L. (2010) 'Reflective ability rubric and user guide'. MedEdPORTAL Publications. 2010;6:8133. [online] http://dx.doi.org/10.15766/mep_2374-8265.8133

Paget, T. (2001) 'Reflective practice and clinical outcomes: Practitioners' views on how reflective practice has influenced their clinical practice'. Journal of Clinical Nursing 10 (2), 204-214. doi: 10.1111/i.1365-2702.2001.00482.x

Peterkin, A., Roberts, M., Kavanagh, L., and Havey, T. (2012) 'Narrative means to professional ends: New strategies for teaching CanMEDS roles in Canadian medical schools'. Canadian Family Physician 58 (10), e563-e569

Plack, M. M., Dunfee, H., and Rindflesch, A. (2008) 'Virtual action learning sets: A model for facilitating reflection in the clinical setting'. Journal of Physical Therapy Education 22 (3), 33-42

Plack, M. M. and Greenberg, L. (2005) 'The reflective practitioner: Reaching for excellence in practice'. Pediatrics 116 (6), 1546-1552. doi: 10.1542/peds.2005-0209

Roche, A. and Coote, S. (2008) 'Focus group study of student physiotherapists' perceptions of reflection'. Medical Education 42 (11), 1064-1070. doi:10.1111/j.13652923.2008.03178.x

Schön, D. A. (1987) Educating the Reflective Practitioner. San Francisco: Jossey-Bass

Sobral, D. T. (2005) 'Medical students' mindset for reflective learning: A revalidation study of the reflection-in-learning scale'. Advances in Health Sciences Education 10 (4), 303-314. doi:10.1007/s10459-005-8239-0

Stark, P., Roberts, C., Newble, D., and Bax, N. (2006) 'Discovering professionalism through guided reflection'. Medical Teacher 28 (1), e25-e31. doi: 10.1080/01421590600568520 
Stein, D. (2000) Teaching Critical Reflection. (Myths and Realities No. 7). Columbus, OH: ERIC Clearinghouse on Adult, Career, and Vocational Education. (ED445256). [online] Retrieved from http://www.calpro-online.org/eric/docs/mr00024.pdf

Teekman, B. (2000) 'Exploring reflective thinking in nursing practice' Journal of Advanced Nursing 31 (5), 1125-1135. doi:10.1046/i.1365-2648.2000.01424.x

Thomas, P. A. and Goldberg, H. (2007) 'Tracking reflective practice-based learning by medical students during an ambulatory clerkship'. Journal of General Internal Medicine 22 (11), 1583-1586. doi:10.1007/s11606-007-0315-0

Toy, E. C., Harms, K. P., Morris Jr, R. K., Simmons, J. R., Kaplan, A. L., and Ownby, A. R. (2009) 'The effect of monthly resident reflection on achieving rotation goals'. Teaching and Learning in Medicine 21 (1), 15-19. doi: 10.1080/10401330802384276

Tsang, A. K. (2012) 'Oral health students as reflective practitioners: Changing patterns of student clinical reflections over a period of 12 months'. Journal of Dental Hygiene, 86 (2), 120-129

Wald, H. S., Borkan, J. M., Taylor, J. S., Anthony, D., and Reis, S. P. (2012) 'Fostering and evaluating reflective capacity in medical education: Developing the REFLECT rubric for assessing reflective writing'. Academic Medicine 87 (1), 41-50. doi:10.1097/ACM.0b013e31823b55fa

Wald, H. S., Davis, S. W., Reis, S. P., Monroe, A. D., and Borkan, J. M. (2009) 'Reflecting on reflections: Enhancement of medical education curriculum with structured field notes and guided feedback'. Academic Medicine 84 (7), 830-837. doi:10.1097/ACM.0b013e3181a8592f

Walker, R., Cooke, M., Henderson, A., and Creedy, D. K. (2013) 'Using a critical reflection process to create an effective learning community in the workplace'. Nurse Education Today 33 (5), 504-511. doi:10.1016/..nedt.2012.03.001

White, S., Fook, J., and Gardner, F. (2006) Critical Reflection in Health and Social Care. Maidenhead, UK: McGraw-Hill Education

Williams, R. M., Sundelin, G., Foster-Seargeant, E., and Norman, G. R. (2000) 'Assessing the reliability of grading reflective journal writing'. Journal of Physical Therapy Education 14 (2), 23-26

Wong, F. K., Kember, D., Chung, L. Y., and Yan, L. (1995) 'Assessing the level of student reflection from reflective journals'. Journal of Advanced Nursing 22 (1), 48-57. doi:10.1046/j.1365-2648.1995.22010048.x

Wright, L. and Lundy, M. (2012) 'Blogging as a tool to promote reflection among dietetic and physical therapy students during a multidisciplinary international service-learning experience'. Journal of Allied Health 41 (3), 73E-78E 